\title{
KARAKTERISTIK PENGETAHUAN TENTANG LAKTASI DENGAN TEKNIK MENYUSUI PADA KALANGAN KADER POSYANDU DI KOTA MALANG
}

\author{
Wira Daramatasia \\ STIKES Widyagama Husada Malang \\ wira.daramatasia@gmail.com \\ Disampaikan dalam Seminar LPPMK STIKES Widyagama Husada \\ 27 Desember 2014
}

\begin{abstract}
Health Data in Malang known that the scope of exclusive breastfeeding in 2009 amounted to $58.47 \%$, the coverage of exclusive breastfeeding is still relatively low, compared to the national target of $80 \%$. To achieve success in breastfeeding infants should be supported by a good lactation management and proper breastfeeding techniques in order to maximize the benefits of breast milk. Posyandu cadre active role in contributing to energy and thoughts to improve public health is essential. This study aims to investigate the characteristics of knowledge about lactation breastfeeding technique at thePosyandu cadres in Malang and the relationship with the attitude of cadres Posyandu knowledge about breastfeeding techniques. This research method is a survey Analytical cross-sectional approach. Sampling with simple random sampling technique. The number of samples of this study amounted to 50 respondents of the total population posyandu cadres representing 5 districts in Malang. The research instrument used questionnaires and observation sheets in the form of a checklist. The data obtained by the respondent characteristics include age, education, occupation, and time/long been a posyandu cadre, then the variable knowledge about lactation and breastfeeding techniques posyandu cadres. Correlation analysis of data using Somers'd. The results of the research that posyandu cadre Knowledge about breastfeeding mostly good number(68\%), posyandu cadres attitude about breastfeeding techniques mostly less (62\%). There was no significant correlation between knowledge cadres Posyandu with attitudes about breastfeeding technique $(p>0,05)$.
\end{abstract}

Keywords: Posyandu, lactation, breastfeedingtechnique 


\begin{abstract}
Abstrak
Data kesehatan di Kota Malang diketahui bahwa cakupan ASI eksklusif pada tahun 2009 sebesar 58,47\%, cakupan ASI eksklusif ini masih relatif rendah jika dibandingkan dengan target nasional 80\%. Untuk mencapai keberhasilan pemberian ASI pada bayi harus didukung oleh manajemen laktasi yang baik dan teknik menyusui yang tepat agar manfaat dari ASI lebih maksimal. Peran aktif kader posyandu dalam menyumbangkan tenaga dan pikirannya untuk meningkatkan kesehatan masyarakat sangatlah penting. Penelitian ini bertujuan untuk mengetahui karakteristik pengetahuan tentang laktasi dengan teknik menyusui pada kalangan kader posyandu di kota Malang, serta hubungan pengetahuan dengan sikap kader posyandu mengenai teknik menyusui. Metode penelitian ini adalah Survey Analitik dengan pendekatan cross sectional. Pengambilan sampel dengan teknik simple random sampling. Jumlah sampel penelitian ini berjumlah 50 responden dari jumlah populasi kader posyandu yang mewakili 5 kecamatan di Kota Malang. Instrumen penelitian ini menggunakan kuesioner dan lembar observasi berupa checklist. Data yang diperoleh yaitu karakteristik responden meliputi usia, pendidikan, pekerjaan, dan masa/lama menjadi kader posyandu, kemudian variable pengetahuan tentang laktasi dan tehnik menyusui kader posyandu. Analisis data menggunakan Korelasi Somers'd. Hasil penelitian diperoleh bahwa pengetahuan kader posyandu mengenai menyusui sebagian besar baik sejumlah $(68 \%)$, Sikap kader posyandu mengenai teknik menyusui sebagian besar kurang (62\%). Tidak terdapat korelasi yang bermakna antara pengetahuan kader posyandu dengan sikap mengenai tehknik menyusui $(\mathrm{p}>0,05)$.
\end{abstract}

Kata kunci:Posyandu, Laktasi, Teknik Menyusui

\section{PENDAHULUAN}

Angka Kematian Bayi (AKB) merupakan salah satu parameter derajatkesehatan suatu negara.Berdasarkan data UNICEF, AKB diseluruh duniamencapai 4 juta per tahun. Sedangkan di Indonesia sampai dengan tahun 2012AKB masih sebesar 32 kematian per 1000 kelahiran hidup. Angka tersebut masih jauh daritarget Millenium Development Goals (MDGs) yaitu 23 per 1000 kelahiran ( SDKI, 2012). Setelah diteliti lebih mendalam ternyata faktor penyebab utama terjadinyakematian pada bayi baru lahir dan balita adalah tidak dilakukannya inisiasimenyusui dini dan ASI eksklusif.Rendahnya pemberian ASI eksklusif menjadipemicu rendahnya status gizi bayi dan balita. Pemberian ASI Eksklusif dapat menekan AKB dengan mengurangi sebesar 30.000 kematian bayi di Indonesia dan 10 juta kematian bayi di dunia melalui pemberian ASI Eksklusif selama enam bulan sejak jam pertama kelahirannya tanpa memberikan makanan dan minuman tambahan kepada bayi.

Berdasarkan data dari UNICEF, pemberian ASI Ekslusif di Indonesiamasih jauh dari rata-rata dunia yaitu $38 \%$. Sedangkan menurut SDKI, 2007menunjukan bahwa jumlah bayi yang mendapatkan ASI eksklusif mengalamipenurunan menjadi $7,2 \%$, tetapi pada pemberian susu formula mengalamipeningkatan menjadi $27,9 \%$. Menurut Dinas Kesehatan Malang, cakupan ibuyang memberikan ASI eksklusif di Malang masih mencapai $58,47 \%$, angka inimasih jauh dari target cakupan ASI ekslusif di Malang yaitu $80 \%$, angka ini juga merupakan target 
cakupan ASI eksklusif Nasional.Untuk mencapai keberhasilan dalam pemberikan ASI pada bayi harusdidukung pula dengan manajemen laktasi yang baik dan teknik menyusui yangbenar agar manfaat dari ASI tersebut juga lebih maksimal.

Dalam

upayameningkatkanpenggunaan Air Susu Ibu (ASI)menunjukkan bahwa hambatanutama penggunaan ASI adalah kurangnya pengetahuan ibu yang benar tentangASI dan tehnik menyusui.ASI dan tehnik menyusui umumnya dianggap hal yang biasa yangtidak perlu di pelajari. Manajemen laktasi atau cara menyusui yang kurangtepat,serta adanya mitos-mitos yang menyesatkan sering menghambatpemberian ASI (Roesli, 2005).Masih rendahnya angka keberhasilan pemberian ASI ekslusif dipengaruhi oleh beberapa faktor yaitu adanya perubahan sosial budaya seperti ibu bekerja, sehingga bayi diberikan MP-ASI sebelum usia 6 bulan, dan kepercayaan bahwa susu botol lebih bergengsi dari pada ASI. Faktor lain yang mendukung adalah kurangnya dukungan dari keluarga ataupun masyarakat sekitar untuk memberikan ASI eksklusif pada bayi usia 0-6 bulan (Rahma, 2008).

Menyadari akan arti pentingnya peran aktif masyarakat dalam menunjang keberhasilan pembangunan dalam bidang kesehatan diperlukan adanya agen-agen pembangunan yang dapat menumbuhkan kesadaran masyarakat untuk berpartisipasi dalam pembangunan. Partisipasi masyarakat dalam pembangunan kesehatan yang mempunyai peran besar salah satunya adalah Kader Pos Pelayanan Terpadu (Posyandu) (Emi, 2006).Kader-kader posyandu pada umumnya adalah relawan yang berasal dari tokoh masyarakat yang dipandang memiliki kemampuan lebih dibanding anggota masyarakat lainnya (Hemas, 2007).

Upaya peningkatan peran serta masyarakat antara lain melalui sistem pengkaderan dengan pelatihan, penyuluhan, dan bimbingan untuk menumbuhkan sikap mandiri sehingga mampu menggali dan memanfaatkan sumber daya yang tersedia serta menumbuhkan dan memecahkan masalah yang dihadapi guna mencapai pelayanan yang optimal. Untuk itu diperlukan kader kesehatan yang baik, yang dapat menyumbangkan tenaga dan pikirannya untuk meningkatakan kesehatan masyarakat (Dinkes Jatim, 2006).

Penelitian ini bertujuan untuk mengetahui hubungan pengetahuan kader posyandu tentang laktasi dengan tehnik menyusui di Kota Malang. Dengan harapan hasil penelitian ini dapat menjadi bahan kader untuk meningkatkan cakupan ASI eksklusif.

\section{METODE PENELITIAN}

Rancangan dalam penelitian ini adalah survey analisis dan pengambilan data dilakukan dengan pendekatan secara cross sectional. Penelitian ini untuk mengetahui hubungan pengetahuan kader posyandu tentang laktasi dengan tehnik menyusui (laktasi).

Populasi dalam penelitian ini adalah semua kader posyandu yang berada di wilayah Kota Malang yang terdiri dari 5 kecamatan (Klojen, Kedungkandang,Sukun, Blimbing dan Lowokwaru). 
Lokasi Penelitian ini dilakukan di beberapa Posyandu yang mewakili masing-masing kecamatan di wilayah kota Malang (Klojen, Kedungkandang, Sukun, Blimbing dan Lowokwaru) Propinsi Jawa Timur. Pelaksanaan dilakukan dengan menjaga privacy dan kerahasiaan responden.

Analisis Statistik pada penelitian ini meliputi analisis univariat dan bivariate. Analisis univariat antara lain: usia, pendidikan, pekerjaan, dan masa/lama menjadi kader posyandu.Analisis Bivariat. Analisis bivariat yang dilakukan pada penelitian ini adalah pengetahuan kader mengenai laktasi dan tehnik menyusui/laktasi.Jenis uji statistikmenggunakan uji korelasi dari somers'd

\section{HASIL DAN PEMBAHASAN}

\section{Karakteristik Responden}

Karakteristik responden kader Posyandu diambil dari 5 kecamatan seluruh kota Malang (Kecamatan Klojen, Kecamatan Kedung Kandang, Kecamatan Sukun, kecamatan Belimbing dan kecamatan Lowok Waru). Karakteristik responden yang dikaji dalam penelitian ini antara lain: usia, pendidikan, pekerjaan, dan masa/lama menjadi kader posyandu. Tabel 1 berikut ini menyajikan karakteristik responden kader posyandu Kota Malang.
Tabel 1: Karakteristik Responden Kader Posyandu Kota Malang Bulan Juli-September 2014 ( $N=50)$

\begin{tabular}{|c|c|c|c|}
\hline No & Karakteristik Responden & $\mathbf{N}$ & $\%$ \\
\hline \multirow[t]{5}{*}{1} & Kategori Usia & & \\
\hline & - $\quad<30$ tahun & 0 & 0 \\
\hline & - $\quad 30$ tahun s.d 40 tahun & 6 & 12 \\
\hline & - $\quad 40$ tahun s.d 50 tahun & 18 & 36 \\
\hline & - $\quad>50$ tahun & 26 & 52 \\
\hline \multirow[t]{5}{*}{2} & Tingkat Pendidikan & & \\
\hline & - $\quad \mathrm{SD}$ & 9 & 18 \\
\hline & - $\quad$ SMP & 4 & 8 \\
\hline & - $\quad$ SMA & 26 & 52 \\
\hline & - $\quad$ Perguruan Tinggi & 11 & 22 \\
\hline \multirow[t]{3}{*}{3} & Pekerjaan & & \\
\hline & - $\quad$ Ibu Rumah Tangga & 46 & 92 \\
\hline & - Swasta & 4 & 8 \\
\hline \multirow[t]{4}{*}{4} & Masa Mengabdi sebagai Kader & & \\
\hline & - $\quad<5$ tahun & 9 & 18 \\
\hline & - 5 tahun s.d 10 tahun & 9 & 18 \\
\hline & - $\quad>10$ tahun & 32 & 64 \\
\hline
\end{tabular}

Tabel 1 diatas menyajikan karakteristik responden kader posyandu yang berpartisipasi dalam penelitian ini.Hasil analisis univariat menunjukan bahwa sebagian besar responden dalam penelitian ini berusia diatas 50 tahun, yaitu berjumlah 26 orang (52\%).Sebagian besar tingkat pendidikan kader posyandu adalah SMA, yaitu berjumlah 26 orang (52\%). Hasil analisis univariat juga menunjukan bahwa pekerjaan kader posyandu bekerja sebagai ibu rumah tangga, yaitu sejumlah46 orang (92\%), banyaknya responden ibu rumah tangga yang berperan sebagai kader posyandu hal ini dikarenakan mereka memiliki banyak waktu luang yang dapat digunakan untuk mengisi waktu disamping menambah ilmu dibidang kesehatan sebagai kader posyandu jugameningkatkan sosialisasi dimasyarakat. Lama responden mengabdi sebagai kader posyandu sebagian besar lebih dari 10 tahun, yaitu sejumlah 32 orang (64\%), 
lamanya pengabdian kader posyandu memiliki alasan bahwa sebagai bagian dari masyarakat, responden bangga dapat ikut serta berperan aktif secara sukarela dalam meningkatkan kesehatan masyarakat, hal ini sesuai dengan tujuan pembentukan kader yaitu mengikutsertakan masyarakat secara aktif dan bertanggung jawab. Keikutsertaan masyarakat dalam meningkatkan efisiensi pelayanan adalah dasar terbatasnya daya dan dengan operasional Posyandu yang akan memanfaatkan sumber daya yang ada dimasyarakat secara optimal (Yulifah, 2005).

Karakteristik responden kader posyandu yang dikaji lainnya adalah tingkat pengetahuan dan sikap kader posyandu mengenai laktasi. Berikut ini merupakan tabel yang menyajikan tingkat pengetahuan dan sikap kader posyandu mengenai laktasi (tabel2).

\section{Tabel 5.2: Karakteristik Tingkat} Pengetahuan dan Sikap Kader Posyandu Mengenai Laktasi

\begin{tabular}{|c|c|c|c|}
\hline No & Karakteristik Responden & $\mathbf{N}$ & $\%$ \\
\hline \multirow[t]{7}{*}{1} & Tingkat pengetahuan & & \\
\hline & kader posyandu mengenai & & \\
\hline & laktasi & & \\
\hline & - $\quad$ Baik & 34 & 68 \\
\hline & - Cukup & 16 & 32 \\
\hline & - $\quad$ Kurang & 0 & 0 \\
\hline & - $\quad$ Tidak Baik & 0 & 0 \\
\hline \multirow[t]{5}{*}{2} & $\begin{array}{l}\text { Sikap kader posyandu } \\
\text { mengenai laktasi }\end{array}$ & & \\
\hline & - $\quad$ Baik & 0 & 0 \\
\hline & - Cukup & 1 & 2 \\
\hline & - $\quad$ Kurang & 31 & 62 \\
\hline & - $\quad$ Buruk & 18 & 36 \\
\hline
\end{tabular}

Berdasarkan tabel 2 hasil analisis univariat tingkat pengetahuan kader posyandu mengenai laktasi sebagian besar berpengetahuan baik, yaitu sejumlah 34 orang (68\%), dan sisanya berpengetahuan cukup yaitu sejumlah 16 orang (32\%). Meskipun sebagian besar responden memiliki pengetahuan yang baik mengenai laktasi, namun berdasarkan item kuisioner pengetahuan tentang laktasi banyak responden yang belum mengetahui (menjawab salah). Beberapa pengetahuan yang belum responden ketahui tentang laktasi adalah : bahwa ibu menyusui bayi akan berhasil meski puting payudara yang terbenam atau datar, karena bentuk puting maupun ukuran besar atau kecilnya payudara bukan merupakan kendala dalam menyusui. kemudian kebutuhan bayi untuk menyusu bukan berdasarkan jadwal namun berdasarkan kebutuhan (on demand) dengan demikian semakin sering frekuensi ibu menyusui bayi maka jumlah ASI yang diproduksi semakin banyak, disamping itu jumlah ASI yang dihasilkan oleh payudara juga tergantung pada isapan bayi, karena isapan bayi merupakan stimulasi dalam produksi ASI, melalui reflek prolaktin dan reflek aliran (letdown reflex). Item pengetahuan lain yang kurang diketahui oleh responden adalah manfaat ASI selain meningkatkan daya tahan tubuh, berpengaruh pada tumbuh kembang dan kecerdasan, diketahui ASI dapat mencegah berbagai penyakit infeksi (diare, infeksi saluran nafas, infeksi telinga, pneumonia, infeksi saluran kemih) dan penyakit lainnya (obesitas, diabetes, alergi penyakit, inflamasi saluran cerna, kanker). Hal ini disebabkan didalam ASI mengandung Sig A (Secretory Imunoglubulin A) yang merupakan sistem pertahanan tubuh khususnya dalam pematangan saluran pencernaan bayi. Suasana asam yang 
terbentuk akibat masukan ASI merupakan sinyal pembentukan mukus pada saluran cerna. Peningkatan kadar SIg A berkorelasi dengan peningkatan sistem pertahanan saluran cerna terhadap infeksi, sedangkan mukus yang melapisi permukaan saluran cena berfungsi sebagai barrier mikroorganisme tidak dapat masuk ke aliran darah. Posisi yang tepat dalam menyusui merupakan pengetahuan lain yang kurang diketahui oleh responden. Mulai persiapan, saat dan sesudah menyusui, khususnya perlekatan antara payudara ibu dengan mulut bayi. Mengetahui posisi tepat saat ibu menyusui bayi dengan baik dan benar merupakan salah satu kunci keberhasilan proses menyusui.

Sikap responden kader posyandu dalam penyampaian mengenai tehnik menyusui/laktasi kepada masyarakat,khusunya ibu hamil dan ibu menyusui sebagian besar memiliki sikap kurang yaitu sejumlah 31 orang (62\%).Sikap kurang dari kader posyandu mengenai teknik menyusui (laktasi) terutama tehnik saat menyusui bayi disamping persiapan dan sesudah menyusui bayi. Kecenderungan sikap kurang kader posyandu dalam penyampaian mengenai tehnik menyusui/laktasi kepada masyarakat disebabkan:

1. Penyuluhan kepada kader posyandu oleh tenaga kesehatan mengenai manajemen laktasi tidak disertai pelatihan khusus mengenai tehnik menyusui (kalaupun ada pelatihan bersifat demonstrasi) sehingga kader posyandu tidak semuanya melakukan kegiatan/praktek tehnik menyusui.

2. Tidak ada/kurangnya pendampingan langsung dari tenaga kesehatan pada kader posyandu saat memberikan penyuluhan maupun implementasi tehnik menyusui kepada masyarakat khususnya ibu hamil dan ibu menyusui.

3. Kurang/hampir tidak adanya evaluasi tenaga kesehatan dari PKM khusunya terhadap kepuasan masyarakat (ibu hamil dan ibu menyusui) mengenai tehnik menyusui yang telah diberikan oleh kader posyandu.Keberhasilan menyusui salah satunya didukung dengan tehnik menyusui yang baik dan benar, mulai dari posisi bayi, cara stimulasi awal menyusui, perlekatan mulut bayi dengan payudara ibu sampai dengan cara menyedawakan bayi setelah menyusui.

Hubungan Pengetahuan Kader Posyandu Tentang Laktasi Dengan Sikap Tekhnik Menyusui

Analisis bivariat pada penelitian ini dilakukan untuk mengetahui hubungan pengetahuan kader posyandu tentang laktasi dengan tekhnik menyusui.Berikut ini tabel yang menyajikan hasil analisis bivariat hubungan pengetahuan kader posyandu tentang laktasi dengan tekhnik menyusui. 
Tabel 3: Hubungan Pengetahuan Kader Posyandu Tentang Laktasi Dengan Sikap Tekhnik Menyusui

\begin{tabular}{llcccccc}
\hline & & \multicolumn{3}{c}{ Sikap } & Total & $\mathrm{r}$ & $\mathrm{p}$ \\
\cline { 2 - 5 } & & Cukup & Kurang & Buruk & & & \\
\hline \multirow{2}{*}{ Pengetahuan } & Baik & 0 & 23 & 11 & 34 & 0,072 & 0,651 \\
\cline { 2 - 7 } & Cukup & 1 & 8 & 7 & 16 & & \\
\hline Total & & 1 & 31 & 18 & 50 & & \\
\hline
\end{tabular}

Berdasarkan tabel 3 mengenai hubungan pengetahuan kader posyandu tentang laktasi dengan Sikap tekhnik menyusui yang dianalisis menggunakan uji korelasi somers'd nilai $\mathrm{r}=0,072$ (sangat lemah) dengan nilai $\mathrm{p}=0,651(\mathrm{p}>0,05)$ tidak terdapat korelasi yang bermakna antara pengetahuan kader posyandu dengan sikap mengenai tehknik menyusui. Bahkan hasil tabulasi silang antara pengetahuan kader posyandu tentang laktasi dengan Sikap tekhnik menyusui juga menunjukan kader posyandu dengan pengetahuan baik memiliki sikap kurang mengenai tehnik menyusui sejumlah 23 orang (46\%) dan sikap buruk sejumlah 11 orang (22\%). Rendahnya hubungan pengetahuan kader posyandu tentang laktasi dengan Sikap tekhnik menyusui.dikarenakan sebagian besar usia kader posyandu lebih dari 50 tahun yang sebagian besar pula merupakan ibu rumah tangga. Usia kader yang sebagian besar dari 50 tahun, disamping memiliki keterbatasan fisik dalam beraktifitas, kader posyandu hanya mengisi waktu kosong. Hal inilah yang menyebabkan kader posyandu tidak maksimal/kurang mau untuk mengembangkan

keilmuannya.Meskipun beberapa Posyandu sering kali diberikan penyuluhan mengenai manajemen laktasi yang didalamnya terdapat tehknik menyusui.
Dalam penyuluhan manajemen laktasi yang diberikan oleh tenaga kesehatan dari PKM terdapat materi tehnik menyusui namun bersifat demonstrasi.Kalaupun ada kader yang mempraktekkan tehnik menyusui hanya beberapa orang saja.Hal ini karena keterbatasan waktu penyuluhan sehingga untuk melaksanakan praktek (peningkatan soft skills) sangat terbatas, selain itu materi penyuluhan posyandu yang beragam memerlukan waktu tersendiri dalam penyampaiannya.Keterbatasan waktu penyuluhan yang disertai pelatihan perlu dijadwalkan disertai implementasi hasil pelatihan kepada masyarakat langsung khusunya pada ibu hamil dan ibu menyusui.Dengan demikian pengetahuan yang sudah baik dapat didukung oleh sikap yang baik pula.

\section{KESIMPULAN DAN SARAN Kesimpulan}

1. Pengetahuan kader posyandu mengenai menyusui sebagian besar baik sejumlah (68\%),

2. Sikap kader posyandu mengenai teknik menyusui ssbagian besar kurang (62\%).

3. Tidak terdapat korelasi yang bermakna antara pengetahuan kader posyandu dengan sikap mengenai tehknik menyusui

\section{Saran}

1. Memaksimalkan penyuluhan dan pelatihan oleh tenaga kesehatan 
(khususnya tenaga kesehatan dari PKM) kepada kader posyandu mengenai manajemen laktasi, khusunya tehnik menyusui dengan mempraktekkan (meningkatkan soft skills).

2. Mengimplementasikan langsung hasil pelatihan kader posyandu kepada masyarakat terutama pada Ibu hamil dan ibu menyusui, serta pendampingan kader posyandu oleh tenaga kesehatan khususnya pada awal implementasi tehnik menyusui yang baik dan benar.

3. Tenaga kesehatan khususnya tenaga kesehatan dari PKM senantiasa mengevaluasi kader posyandu secara periodik berkaitan dengan penerapan manajemen laktasi kepada masyarakat.

\section{REFERENSI}

Arikunto, Suharsimi.2006. Prosedur Penelitian Suatu Pendekatan Praktek. Jakarta: PT. Rineka Cipta.

Bobak.2004. Keperawatan Maternitas. Jakarta, EGC.

Cahyo Ismawati S., 2010. Posyandu dan Desa Siaga.Yogyakarta. Nuha Medika

Depkes, RI. 2006. Pos Pelayanan Terpadu

(Posyandu). Diakses tanggal 8 september 2013 dari www. google.com

Depkes, RI. 2007. Rumah Tangga Sehat Dengan perilaku Hidup Bersih dan Sehat.Jakarta, Depkes RI.

Dinas Kesehatan Jatim. 2006. Profil Kesehatan Propinsi Jawa Timur.

Dinkes, Jatim. 2008. Peran Serta Kader Posyandu. Diakses tanggal 17 April 2013 dari www. peran serta kader posyandu. Com
Emi, Mastutik Titik.2006. Partisipasi Masyarakat dalam Posyandu. Jakarta. Salemba Medika.

Hemas.2007. Kader Posyandu. Diakses tanggal 15 september 2013 dari www.wordpress.com

Moody, Jane. 2005. Menyusui Cara Mudah, Praktis Nyaman. Jakarta, Arcan

Perinasea.2011. Bahan Bacaan Manajemen Laktasi, Cetakan Ke5.Jakarta : Perkumpulan Perinatologi Indonesia.

Rahma.2008. Proses Mekanisme Produksi ASI dan Faktor Yang Mempengaruhi Produksinya. Di akses tanggal 19 september 2013 dari www.wordpress.com

Ramaiah, Savitri. 2007. ASI dan Menyusui. Jakarta: PT. Bhuana Ilmu Populer.

Roesli, Utama. 2005. Mengenal ASI Ekslusif. Jakarta, Arcan

Roesli, Utami. 2008. Inisiasi Menyusui Dini Plus ASI Eksklusif. Jakarta: Pustaka Bunda

Saleha, Sitti. 2009. Asuhan Kebidanan Pada Masa Nifas. Jakarta, Salemba

SDKI.2007.Survey Demografi dan kesehatan Indonesia, Di akses Tanggal 19 september 2013 dari www.infodokterku.com 